\title{
Effects Financial Media have on Firm Value and Suggestions for Investor Relations Media Strategy
}

\author{
Wang Ying $^{1,2,3,4, a}$, Zhang Tianzhen ${ }^{5, b}$, Song Jiameng ${ }^{6, c}$ \\ ${ }^{1}$ Shaanxi Provincial Land Engineering Construction Group Co., Ltd., Xian710054, China; \\ ${ }^{2}$ Institute of Land Engineering and Technology, Shaanxi Provincial Land Engineering Construction Group \\ Co., Ltd, Xian 710054, China; \\ ${ }^{3}$ Key Laboratory of Degraded and Unused Land Consolidation Engineering, the Ministry of Land and \\ Resources, Xian 710054, China; \\ ${ }^{4}$ Shaanxi Provincial Land Consolidation Engineering Technology Research Center, Xian 710054, China; \\ ${ }^{5}$ Xueweigui education Co., Ltd., Beijing 100000, China; \\ ${ }^{6}$ HILOGICLOUD Intelligent Logistics Co., Ltd., Xian 710000, China. \\ awangying3133@yeah.net, btz19911128@163.com, ‘jiam.song@HiLogiCloud.com
}

Keywords: financial media, firm value, suggestions for investor relations media strategy.

\begin{abstract}
Three main effects that financial media have on firm value have been outlined. The first outcome is that financial media could influence the share price of a firm, and the positive news can predict higher stock price normally, and vice versa. The second demonstration shows that financial media could help the firm to disseminate brand value and employ more outstanding staff, and the assistance is more significant with local media. Additionally, financial media could increase the success rate of firm's IPO and subsequent profits after the IPO.
\end{abstract}

\section{Introduction}

Financial media exists in our daily life and affecting so many aspects as other types of media do. There are numerous famous financial media platforms, such as The Financial Times, Business Week and Bloomberg News. Nearly all of them could have significant effects on firms, especially the companies that are easiest to be reported as Davis (2006) outlined - FTSE100 or S\&P500, fashionable business, companies being takeovers or M\&A (i.e. mergers and acquisitions) and companies in crisis.

In first sector, this essay will mainly use Davis (2006)'s concepts about differences between individual investors and institutional investors, and Griffin, Hirschey \& Kelly (2011)'s hypotheses about the gap between developed markets and emerging markets to attempt to demonstrate that financial media could influence the share price of a firm, while the power of this influence can be different because of the categories of investors, scales of companies and situations of markets.

In the second part, Johnson \& Scholes (2002)' stakeholder mapping could be useful to illustrate that financial media has an essential effect on firm's brand value and recruitment. Moreover, the third part will concentrate on illustrating the functions of media coverage about pre-Initial Public Offering on the firm's long-term profits by referring to Liu, Sherman \& Zhang (2014)'s research.

Investor relations media (IRM) is a significant element in the analysis of effects on firms that financial media caused. In this essay, IRM and investor relations offerings (IROs)' strategies will be suggested in each part. And those suggestions are mainly about how they should do to utilise financial media most effectively to help the firm gain more profits.

\section{Relationships between Financial Media and Share Price \& Suggested Strategies for IRM}

Financial media could influence investors' behaviours and then affect the share price of a company. A MORI survey (2000) shows that 64\% and 51\% investors get useful information from 
analysts and newspapers separately (see Appendix1), and the two factors are the highest data in this survey. Normally, most analysts will publish their comments on the financial media to gain profits and their thoughts are the main sources for journalists to edit in news. Hence, financial media is a significant way to guide the investment to affect the stock price.

However, institutional investors are slightly impacted by the financial news media, since the information on print media is outdated compared with other sources that professional fund managers could gain (Davis, 2006a). Different from individual investors, institutional investors have more chances to meet senior managers in companies, thereby acquiring more specific and realistic information to guide their investment behaviours. Moreover, their knowledge in this area is deeper and wider than financial journalists (Davis, 2006a). An anonymous interview (1998) shows, numerous financial journalists have admitted that they are not professional enough. Hence, there is no reason for the majority of professional fund managers to invest as the media reported. Since institutional investors are strong part of the market that cannot to be ignored, IROs should improve their skills to provide more professional and time-efficient news for IRM to attract those people.

Nevertheless, as Barber \& Odean (2007) state, compared with institutional investors, individual investors will buy more noticeable shares that are disseminated by financial magazines \& newspapers. Furthermore, Davis (2006) also claims that private investors are mostly rely on comments and charts designed by analysts on financial media, because private investors cannot own sources as many as institutional investors and their knowledge level about Finance is relatively lower. Indeed, in real life, individual investors would buy more shares of the company that is reported as a rising "star", and selling shares of those firms struggled with negative press.

Tetlock, Saar-Tsechansky \& Macskassy (2008) say that negative news might forebode the decrease of sales of related firms, and then affecting share price, and vice versa. With the exposure of Tesco's accounting scandal on the media, Tesco's share price shrunk to around 180pence on October 2014, the lowest data since it came into the market (See Appendix 2). Moreover, the famous financial media This is Money (Accessed on 10/05/2015) reported that the selling of stocks largely among private investors is one the main reasons that caused the rapid decrease of Tesco's share price. Even though Laskin (2009) argues that private investors have little influence on share price, we should not ignore them because of the increasing number of private investors. If IROs want to maintain the share price when the negative press comes, they should reassure individual investors immediately by showing the company's confident financial report or trying to gain as much as subsequent positive press.

However, because of the relatively higher awareness about the market among institutional investors, some wise companies' share price may reverse quickly after the negative media report. Once the scandal appeared, most individual investors would sell their holding shares immediately, and institutional investors might buy those stocks in a correspondingly cheaper price to wait for the price claiming again (Joe, Louis \& Robinson 2009). As a result, the majority of firms couldn’t ignore the development of negative elements. With the implementation of effective organisation, people will be convinced again and then the share price would reverse. Financial PR practitioners need to pay for special attentions on helping the company to avoid subsequent negative reports appear again. This is because Chan (2003) and Tetlock (2010) find, the reversing of the share price needs to obey the rule that there is no extra news about this stock.

Nevertheless, financial media is playing an active role to drive the share price up in most of the times, since financial news is relatively positive, especially the local financial media. On one hand, in the numerous types of news, financial news could earn much more than others because of the advertising fees from the firms (Curran, 1978). On the other hand, as comments form analysts are the main resource for financial news, their benefits-oriented behavioural pattern has caused an uncritical and buying recommendations system in most of the financial news (Davis, 2006a). Moreover, for the advertising income and local interests, local media may report the firm much more positively (Gurun \& Butler, 2012). And local financial media could boost the individual investors to buy more shares of the company it reported (Engelberg \& Parsons, 2011). Even though Laskin (2009) claims that IROs don't spend much time on financial media, while it is rather 
important to stock price. Therefore, to increase the share price and profitability of a firm, IROs should supply more positive information for the local financial media to acquire more reports about their companies.

Apart from outlined above, Huth \& Maris's (1992) study found that the share price of small companies is easier to be affected by news than big ones. This is mainly because small-firm shares attracted most individual investors (Tetlock 2007). For large firms, professional investors hold most of their shares and those people are relatively unaffected with financial media, excepting serious scandals are continually reported.

Additionally, the development of market could also influence the result of financial media caused on share price. In the majority of developed markets, share price of a company is changeful with the related media coverage. Griffin, Hirschey \& Kelly (2011) suggest four reasons about this issue, the pre-dissemination of the news, insider trading, news transmission and different accounting quality. For the first reason, Givoly \& Palmon (1982) claim that share price of latereporting firms is insensitive because of the advanced information that investors gain from earlierreporting firms. In developed regions, firms' earnings announcements are always quicker than emerging markets'. For the second one, Griffin, Hirschey \& Kelly (2011) speculate that insider trading is more frequent in emerging markets, and Bhattacharya et al. (2000)'s article has demonstrated that insider trading is the main cause for Mexico's dampened share price reactions. However, this reason is declining because of the implementation of related laws to restrict insider trading.

After the explanation of the last two suggested reasons, the different relationships between share price and financial media in global markets are more clear and reasonable. Griffin, Hirschey \& Kelly (2011) state that share price is more sensitive to financial news in a market with the higher accounting criterion and more sophisticated financial disclosure. Since under these conditions, firms' financial status can be trustworthier. They also hold the statement that journalists in developed markets are normally more skillful to gather useful information to publish on financial media in this information-staggered world (Griffin, Hirschey \& Kelly, 2011). In accordance to that, more specific information could influence share price lager.

In this part, IROs in emerging markets should improve their skills to catch up with the developed markets' IROs firstly, and then IRM should supply more voluntary disclosure information for individual investors to establish a stable relationship with them. In doing so, to help the firm to achieve more trust among the most vulnerable investors - private ones, thereby assisting the firm to transform steadily when the whole market transferring into developed.

\section{Relationships between Financial Media, Firm's Brand Value and Recruitment \& Suggestions for IRM}

Earned media is the main way for companies to gain reputation, and financial news is a kind of earned media that could be useful as well. There are numerous ways for a firm to disseminate its brand value, and the most effective methods including bought media (e.g. Print advertising, Television), earned media (e.g. Reports from the third party, Comments from the public on social media) and owned media (e.g. Official website, Social media brand pages). As CIPR (Accessed on 15/05/2015) states, earned media has the highest credibility in three of them. Moreover, higher reputation could attract more investors (Helm, 2007). In that sense, IROs should attempt to communicate with financial media, especially famous media (e.g. Business Week) to supply brand value information for journalists actively to earn positive report. This could help the firm gain more reputation from the people who see the news and most of them may invest for this firm.

Additionally, the positive press from the local media could help the firm to establish a good reputation in this community and this can be useful for the firm's recruitment. Higher reputation could help the company to employ more outstanding staff but with lower salary, and this is a significant value that taken from financial media. In accordance to Johnson \& Scholes (2002)' stakeholder mapping (see Appendix 3), employees always have high power and high interest in a company. Excellent staff could not only be strong reverse force for a company in future, but also be 
opinion leaders (people who can influence the concepts in certain areas of people around them) among their families and friends. Excellent internal communication could encourage employees to behave actively and popularizing firm's reputation simultaneously. As a result, the people around them may begin to buy the products or the shares of this company, which could increase profitability and stock price of the firm eventually.

For this sector, IRM should consider the utilisation of financial media to attract employees as a long-term benefit. Taking the information about how they encourage their staff and how many benefits that employees can get in this company into consideration, could help the firm to gain more profits from the financial media, especially the local ones.

\section{Relationships between Financial Media and Firm's IPO \& Suggestions for IRM}

Initial public offering (IPO) is the first sale of stocks by a private company to the public. Companies go public is mainly because they want to increase income, adding assets, spreading brand value and attracting employees. And the wide range of financial media news about pre-IPO of a firm could satisfy most of its needs in a long-term return. In line with Bushee and Miller (2012)'s survey, achieving attention from institutional investors and analysts, and earning media report are three effective methods to improve a corporation's perceptibility. However, helping the firm to gain as much as positive financial press about pre-IPO could reach the three targets eventually. In Merton (1987)'s research, investors would prefer to invest on firms that they know or can catch their attention; especially those mentioned venture capital backing ones. Hence, increasing media coverage before IPO could attract more investors.

Furthermore, Van Nieuwerbuigh and Veldkamp (2009) claim that investors and analysts will concentrate on firms what they are familiar with continually. This means that pre-IPO media coverage could exert an enormous effect subsequently. Moreover, highly reported firms could still obtain rising focuses and supports from investors and analysts after IPOs, and the attention-degree gap between non-reported firms and highly-reported firms is widening year by year (Liu, Sherman \& Zhang, 2014). Therefore, IRM should help the firm to gain more positive media coverage before its IPO, as well as, providing venture capital backing information for journalists actively when IROs communicating with media.

There are a lot of ways that financial public relations practitioners (FPRs) and IROs could do through the financial media to help the firm to improve the awareness before IPO and stabilize its condition after the IPO. They can launch events by using editorial methods, electronic ways and publications to make the event more specific. Editorial methods mean that FPRs could invite financial journalists to attend their CEO's roadshows to increase media exposure. Cooperate with some famous national media (e.g. The Wall Street Journal) and local media (e.g. Subway Business) is an effective way to attract potential investors. Electronic ways are more visual to some extent, they can upload the process of roadshows' video on official website and social media (e.g. You tube) to attract clicks. As for publications, this way is easier but efficient as well. IROs can publish related information on their company magazines and newspapers, or just editing them as owned financial brochures. More media coverage they achieved, higher success rate of firm's IPO will be gained.

\section{Conclusion}

In this essay, three main effects that financial media have on firm value have been outlined. The first outcome is that financial media could influence the share price of a firm, and the positive news can predict higher stock price normally, and vice versa. Compared with institutional investors, private investors always behave a more obvious susceptibleness on stocks of a firm with its related financial report, because of the weaker ability to acquire useful information. Meanwhile, media news about smaller companies had a deeper impact on share price than those about larger companies. Furthermore, the higher development of the markets usually means the greater impact that financial media could exert on firms' share price, because of the potential existence of four 
elements (i.e. pre-dissemination news, insider trading, relatively lower accounting standard and not very professional journalists) in emerging markets. In this sector, IROs and IRM should focus on private investors since their investment behaviours are easier to be influenced by financial media. Providing more positive information and voluntary disclosure information for media platforms, especially local media, could help the firm to attract more individual investors. Moreover, if the firm is suffering negative news, IROs should try to help the share price reverse by communicating with journalists to avoid deeper damage and attempting to ensure no extra news being reported about the firm.

The second demonstration shows that financial media could help the firm to disseminate brand value and employ more outstanding staff, and the assistance is more significant with local media. To make it better, FPRs could provide details about how the firm encourages its stakeholders for financial media to gain more reputation and attract more investors, as well as, enhancing internal communication to stimulate employees to be opinion leaders to drive the profitability and investment from the people around them. Additionally, financial media could increase the success rate of firm's IPO and subsequent profits after the IPO. As mentioned above, the attention from investors and analysts of a firm is positively related with the media coverage of pre-IPO, which means the large amount of media report before the IPO could not only help the firm to gain more investors to boost the IPO, but also get more attention after that. IROs in this process should use editorial, electronic, event and publications to help the firm to obtain as much as positive media press.

However, there are still a lot of other effects that finical media have on firms. IRM, as an effective tool that can help the firm to gain more benefits, which should practice continually to enhance skills to catch up with the rapidly developing market and media.

\section{References}

[1]. Barber, BM \& Odean, T . All That Glitters: The Effect of Attention and News on the Buying Behavior of Individual and Institutional Investors. The Review of Financial Studies. vol. 21(2007), No. 2, p. 785-818.

[2]. Bhattacharya, U., H. Daouk, B. Jorgenson, and C. Kehr. When an Event Is Not an Event: The Curious Case of an Emerging Market. Journal of Financial Economics. 2000,p. 55:69-101.

[3]. Bushee BJ, Miller GS. Investor relations, firm visibility, and investor following. Accounting Rev. 2012, p. 87(3):867-897.

[4]. Chan W Stock price reaction to news and no-news: Drift and reversal after headlines. J. Financial Econom. 2003, p. 70(2):223-260.

[5]. Curran, J. “Advertising and the press”, in Curran, J. (Ed.), The British Press: A Manifesto, MacMillan, London. 1978, p. 229-67.

[6]. Davis, A. The role of the mass media in investor relations. Journal of communication management. vol. 10(2006), No. 1, p. $7-17$.

[7]. Engelberg J, Parsons C .The causal impact of media in financial markets. J. Finance 2011, p. 66(1):67-97.

[8]. Givoly, D., \& Palmon, D. Timeliness of annual earnings announcements: Some empirical evidence. Accounting review. 1982, p.486-508.

[9]. Griffin, JM, Hirschey, NH \& Kelly, PJ. How important Is the financial media in global markets?. The Review of Financial Studies, vol. 24(2011), No. 12, p.3941-3992.

[10]. Gurun, UG \& and Butler, AW. Don’t believe the hype: local media slant, local advertising, and firm value. The journal of finance, vol. 67(2012), No. 2, p. 561-597. 
[11]. Helm, S. The role of corporate reputation in determining investor satisfaction and loyalty. Corporate Reputation Review. 2007, 10(1), p. 22-37.

[12]. Huth, W. L., \& Maris, B. A. Large and small firm stock price response to "Heard on the Street” recommendations. Journal of Accounting, Auditing \& Finance. 1992,7(1), p.27-44.

[13]. Joe, JR, Louis, H, \& Robinson, D. Managers' and investors' responses to media exposure of board ineffectiveness. Journal of financial and quantitative analysis. vol. 44(2009), No. 3, pp. 579-605.

[14]. Laskin, A. V. A descriptive account of the investor relations profession a national study. Journal of Business Communication.2009,46(2), p.208-233.

[15]. Liu, L. X., Sherman, A. E., \& Zhang, Y. The long-run role of the media: evidence from initial public offerings. Management Science., 2014, 60(8), p.1945-1964.

[16]. Merton, R. C. A simple model of capital market equilibrium with incomplete information. The journal of finance. 1987,42(3), p. 483-510.

[17]. Tetlock PC. Giving content to investor sentiment: The role of media in the stock market. J. Finance 2007, 62(3):1139-1168.

[18]. Tetlock, P, Saar-Tsechansky, M \& Macskassy, S. More than Words: Quantifying Language to Measure Firm Fundamentals. The Journal of Finance. vol. 63(2008), No. 3, p. 14371467.

[19]. Tetlock PC. Does public financial news resolve asymmetric information? Rev. Financial Stud.2010, 23(9):3520-3557.

[20]. Van Nieuwerburgh S, Veldkamp L Information immobility and the home bias puzzle. J. Finance .2009,64(3):1187-1215.

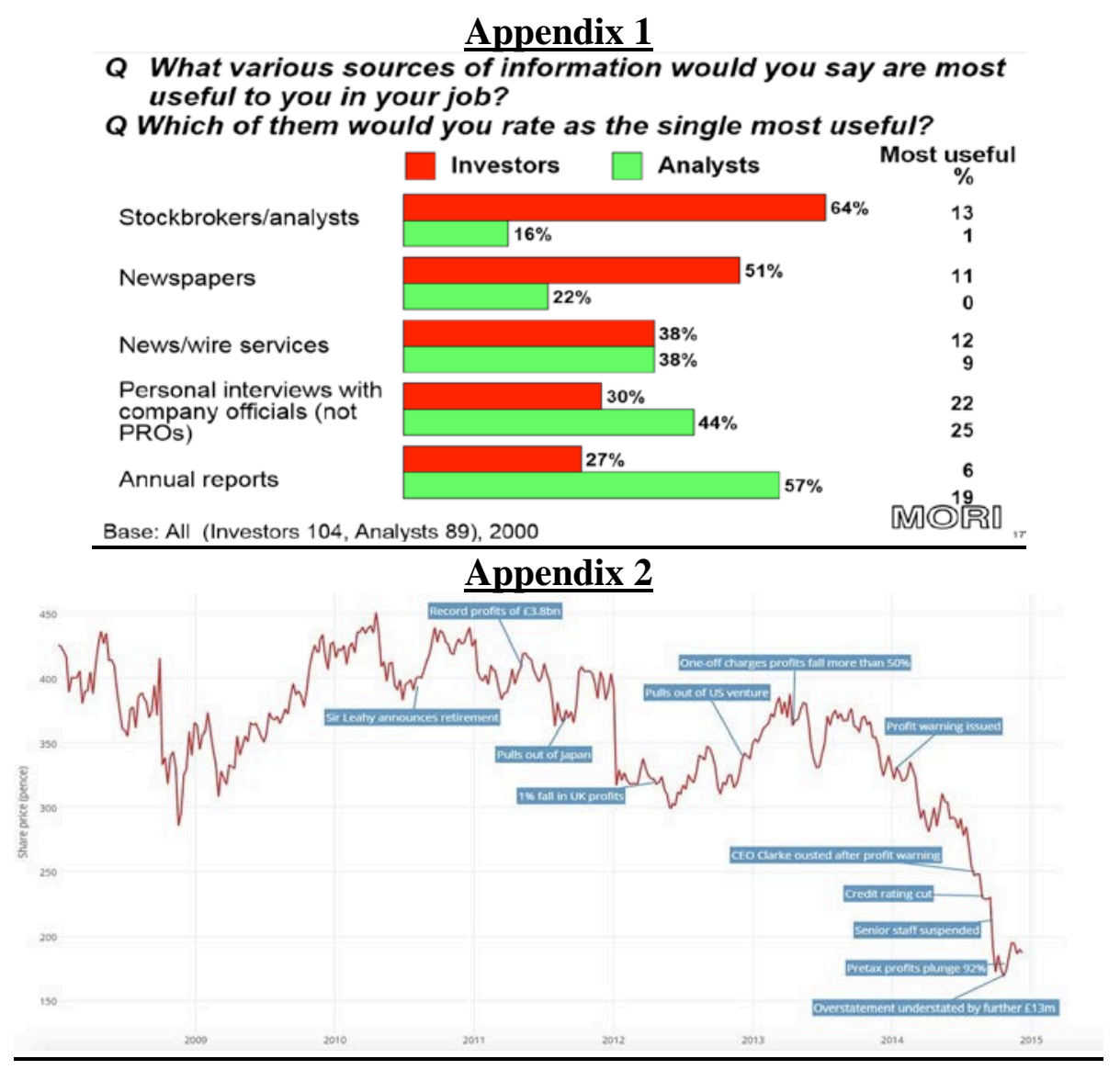




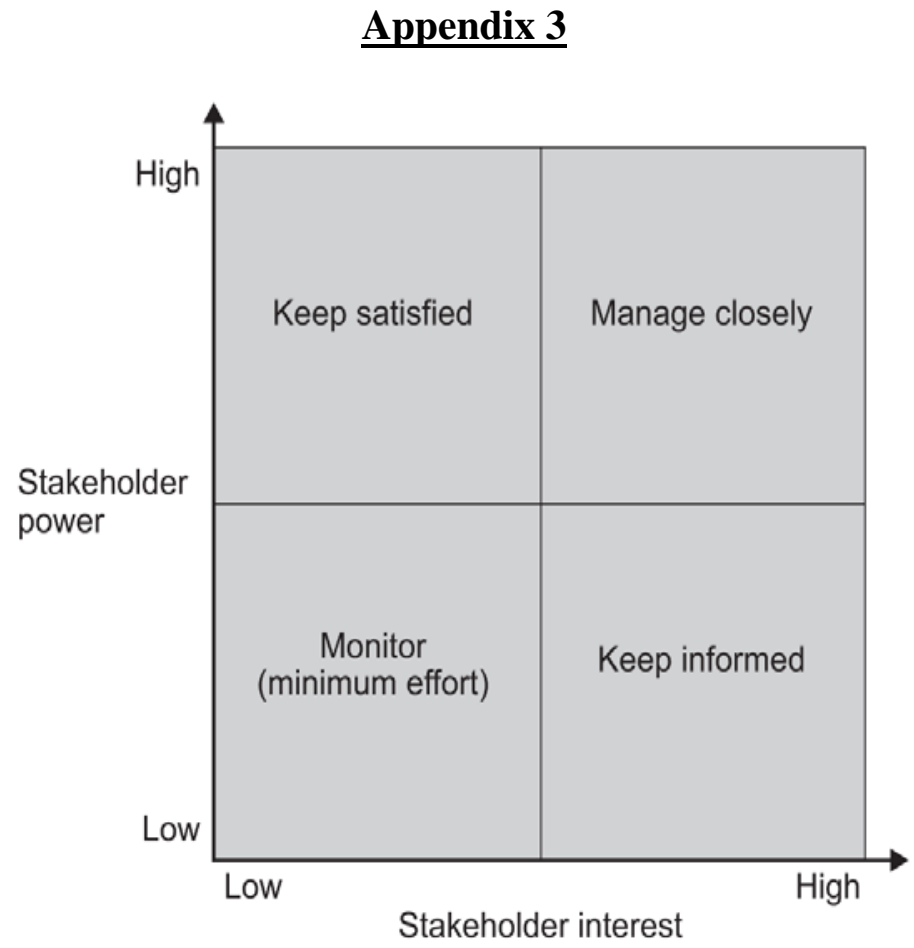

